\title{
Pterygium Colli
}

National Cancer Institute

\section{Source}

National Cancer Institute. Pterygium Colli. NCI Thesaurus. Code C87130.

A cong enital, usually bilateral, thick web-like fold of skin that extends from the acromion to the mastoid process. This deformity is associated with Turner Syndrome and Noonan Syndrome. 